DOI - 10.32743/UniChem.2021.84.6.11858

\title{
ANALYSIS OF THE DISPERSED COMPOSITION OF THE PHOSPHORITE DUST AND THE PROPERTIES OF EMISSION FLUORIDE GASES IN THE PRODUCTION OF SUPERPHOSPHATE MINERAL FERTILIZERS
}

\section{Rasuljon Tojiev}

Doctor of Technical Sciences, Professor, Fergana Polytechnic Institute, Republic of Uzbekistan, Fergana

E-mail: rasuljon1945m@il.ru

Azizbek Isomiddinov

PhD, Associate Professor,

Fergana Polytechnic Institute, Republic of Uzbekistan, Fergana E-mail: isomiddinov1985@mail.ru

Akmaljon Akhrorov

Basic doctoral student, Fergana Polytechnic Institute, Republic of Uzbekistan, Fergana

E-mail: axrorov-2013@mail.ru

Shoiraxon To'ychieva

Assistant of Fergana Polytechnic Institute Republic of Uzbekistan, Fergana E-mail: shoiratuychiyeva@gmail.com

\section{АНАЛИЗ ДИСПЕРСНОГО СОСТОВА ФОСФОРИТНОЙ ПЫЛИ И СВОЙСТВА ВЫБРОСНЫХ ФТОРИСТЫХ ГАЗОВ ПРИ ПРОИЗВОДСТВЕ СУПЕРФОСФАТНЫХ МИНЕРАЛЬНЫХ УДОБРЕНИЙ}

Тожиев Расулжон Жумабаевич д-р техн. наук, проф., Ферганский политехнический институт, Республика Узбекистан, г. Фергана

Исомиддинов Азизбек Саломиддинович д-р техн. наук (PhD), дои. Ферганский политехнический институт, Республика Узбекистан, г. Фергана

Ахроров Акмалюжон Акрамжсон узли базовый докторант, Ферганский политехнический институт,

Республика Узбекистан, г. Фергана

Туйчиева Шоирахон Шухратбековна преподаватель, Ферганский политехнический институт,

Республика Узбекистан, г. Фергана

Bibliographic description: Analysis of the dispersed composition of the phosphorite dust and the properties of emission fluoride gases in the production of superphosphate mineral fertilizers // Universum: химия и биология : электрон. научн. журн. Tojiev R. [и др.]. 2021. 6(84). URL: https://7universum.com/ru/nature/archive/item/11858 


\section{ABSTRACT}

The article presents the results of experimental research on the absorption of secondary gas into the absorbent liquid to clean the secondary gases formed in industrial production processes in a wet cleaning scrubber and determine its optimal technical parameters. In the experiments, hydrogen-fluoride gas, which is released in the reaction environment during the production of superphosphate, was selected as the object. Calcium technical white soda, sodium carbonate soda and technical shampoo 10 in water; Absorption in 20 and 30\% solutions was analyzed in the laboratory. Laboratory tests were performed in two stages, sieve and microscopy, and the results were compared and experimental errors were identified. Standard methods were used in conducting the experiments.

\section{АННОТАЦИЯ}

В статье представлены результаты экспериментальных исследований абсорбции вторичного газа абсорбирующей жидкостью с целью очистки вторичных газов, образующихся в производственных процессах в скруббере мокрой очистки, и определения его оптимальных технических параметров. В проведенных экспериментах в качестве объекта был выбран газообразный фтористый водород, который выделяется в реакционной среде при производстве суперфосфата. Сода кальциевая техническая белая, сода карбонат натрия и технический шампунь 10 в воде; Поглощение в 20 и 30\% растворах анализировали в лаборатории. Лабораторные испытания проводились в два этапа: сито и микроскопия, результаты сравнивались и были выявлены экспериментальные ошибки. При проведении экспериментов использовались стандартные методы.

Keywords: scrubber, dust, secondary gas, hydrogen fluoride, sodium fluoride, superphosphate, ANKT-410, carbonate soda, technical shampoo, absorbent, dusty gas.

Ключевые слова: скруббер, пыль, вторичный газ, фтороводород, фторид натрия, суперфосфат, АНКТ-410, сода карбонатная, технический шампунь, абсорбент, пыльный газ.

\section{Introduction}

Accurate knowledge of the properties of dust gases plays an important role in the correct choice of method of capture or neutralization of dust gases in different states (gaseous, liquid or solid) generated during industrial production, increasing dust capture efficiency and creating energy-efficient structures.

This, in turn, requires the study of the causes of the formation of dust gases from manufacturing plants and the analysis of their physical and chemical properties $[1,2]$.

\section{Research methodology}

To determine the optimal operating parameters of the wet dust scrubber [3] in this article, AC-72M shop of JSC "Ferganaazot", one of the largest chemical enterprises in the Republic of Uzbekistan, produces secondary hydrogen fluoride gas and dust of phosphorite flour. selected. The absorption of the selected hydrogen fluoride gas into the absorbent liquid and the dispersion composition of the phosphorite powder were analyzed $[4,5]$. The established standard methods were used in conducting the experiments $[6,7]$. The experiments were conducted in three stages.

\section{Experimental results}

In the first stage, sources of dust and secondary gas and the causes of their formation were studied. It is known that the process of superphosphate production in JSC "Ferganaazot" consists of mixing phosphorite flour and sulfuric acid in a reaction medium, granulation in a drum granulator-dryer by spraying the mixture with ammonium sulfate and drying of granulated fertilizer and separating of fertilizer into granulometric compositions $[1,8,9]$.

The designed technological line is more energyefficient than existing classical methods and has a high performance in terms of fertilizer quality. The number of mixing rectifiers in the technological line is three, in the process of which mainly two-molecule hydrogen fluoride gas and unreacted phosphorite flour are formed during the reaction. Currently, the company uses cyclone NIOGAS to clean the dust of unreacted phosphorite flour and water as a hollow scrubber and cleaning fluid to neutralize hydrogen fluoride gas. In the current process, the amount of gas and dust mixture in $1 \mathrm{~m}^{3}$ of air was determined experimentally to be $2697.79 \mathrm{mg}$. A multi-factor ANKT-410 gas analyzer was used in the experiments [1].

The experiments were repeated five times and the arithmetic mean was chosen. Figure 1 shows the technological scheme of the production process of superphosphate mineral fertilizers [1]. 


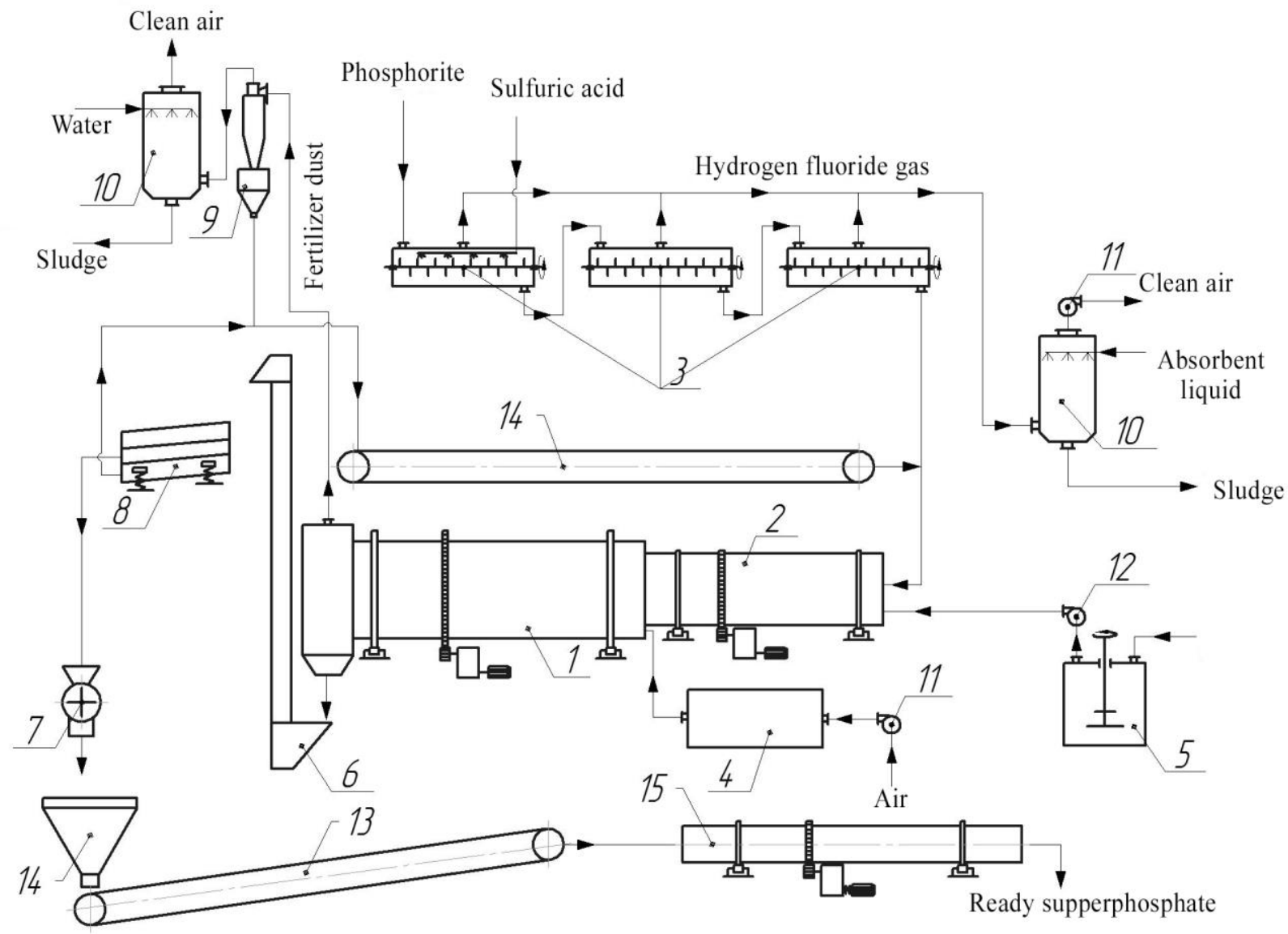

1-drum dryer; 2-drum granulator; Horizontal reactor with 3- mixers; 4-Heater; 5 - Vertical reactor with mixer; 6-bucket elevator; 7 Hammer Crusher; 8- sieve; 9-Cyclone NIOGAS; 10 Hollow scrubber; 11-Fan; 12 - Centrifugal pump; 13-belt conveyor; 14-Supplier bunker; 15-drum refrigerator.

\section{Figure 1. Technological scheme of production of superphosphate mineral fertilizers}

In the second stage, absorbents were selected to neutralize the hydrogen fluoride (2HF) gas. Gas 10; Absorption into 20 and $30 \%$ solution absorbent was analyzed using chemical and microscopic methods (DSM-310 camera and LANGDORPSSESTENGER1603201 brand SM001-CYANS biological microscope were selected). Substances for absorbent were selected in accordance with the requirements of GOST 5100-85.

Given the solubility of the secondary hydrogen fluoride gas and its rapid adaptability to the active environment, calcium technical white soda $\left(\mathrm{Na}_{2} \mathrm{CO}_{3}\right)$, sodium carbonate soda $\left(\mathrm{Na}_{2} \mathrm{CO}_{3} \cdot \mathrm{H}_{2} \mathrm{O}\right.$ washing soda) and technical shaman $\left(\mathrm{C}_{8} \mathrm{H}_{8} \mathrm{O}_{3}\right) \quad 10$ in water; 20 and $30 \%$ solutions were prepared. The chemical reaction was calculated.

$$
\mathrm{Na}_{2} \mathrm{CO}_{3} \cdot \mathrm{H}_{2} \mathrm{O}+\mathrm{HF} \rightarrow \mathrm{NaF}+\mathrm{H}_{2} \mathrm{O}+\mathrm{CO}_{2} \uparrow
$$

Equation (1) shows that when hydrogen fluoride is absorbed into an aqueous solution of calcined technical white soda, water and sodium fluoride solution and carbon dioxide gas are formed.

$$
\mathrm{Na}_{2} \mathrm{CO}_{3} \cdot \mathrm{H}_{2} \mathrm{O}+\mathrm{HF} \rightarrow \mathrm{NaF}+2 \mathrm{H}_{2} \mathrm{O}+\mathrm{CO}_{2} \uparrow
$$

Equation (2) shows that when hydrogen fluoride is absorbed into an aqueous solution of calcium carbonate soda, two molecules of water and a solution of sodium fluoride and carbon dioxide gas are formed. When hydrogen fluoride was absorbed into an aqueous solution of technical shampoo, water and carbonate fluoride solution, as well as carbon dioxide gas, were formed. 10 of the above-selected absorbents in the liquid; 20 and 30\% solutions were prepared and the absorption of hydrogen fluoride gas in an absorbent liquid in $\mathrm{g}$ was determined experimentally [1].

The neutrality ( $\mathrm{pH}$ level) of the obtained wastewater samples was analyzed by the laboratory. The results of the laboratory analysis are presented in Table 1. 
Table 1.

The results of the laboratory analysis

\begin{tabular}{|c|c|c|c|c|}
\hline $\begin{array}{c}\text { Amount of solution, } \\
\mathbf{\%}\end{array}$ & $\begin{array}{c}\text { Amount of } \\
\text { absorbent liquid, gr }\end{array}$ & Sediment name & $\begin{array}{c}\text { The amount of } \\
\text { sediment, gr }\end{array}$ & Wastewater acidity, pH \\
\hline \multirow{3}{*}{10} & 100 & sodium fluoride & 1,88 & 6,5 \\
\cline { 2 - 5 } & 100 & sodium fluoride & 1,11 & 6,14 \\
\cline { 2 - 5 } & 100 & carbonate-photoride & 0,83 & 5,8 \\
\hline \multirow{3}{*}{20} & 100 & sodium fluoride & 3,21 & 7,9 \\
\cline { 2 - 5 } & 100 & sodium fluoride & 2,44 & 7,1 \\
\cline { 2 - 5 } & 100 & carbonate-photoride & 0,98 & 6,8 \\
\hline \multirow{3}{*}{30} & 100 & sodium fluoride & 5,61 & 9,46 \\
\cline { 2 - 5 } & 100 & sodium fluoride & 3,28 & 8,7 \\
\cline { 2 - 5 } & 100 & carbonate-photoride & 1,12 & 8,1 \\
\hline
\end{tabular}

Given the high rate of hydrogen fluoride gas formed during the production process and the fact that $1 \mathrm{~m}^{3}$ of air corresponds to $2697.79 \mathrm{mg}$ of secondary gas and dust, it is advisable to choose a $30 \%$ absorbent to be added to the liquid.
Based on the above, the state of the precipitate formed when hydrogen fluoride is absorbed in a $30 \%$ absorbent liquid was magnified 400 times under a microscope and compared with the experimental results in Table 1. (Figures 2, 3 and 4).

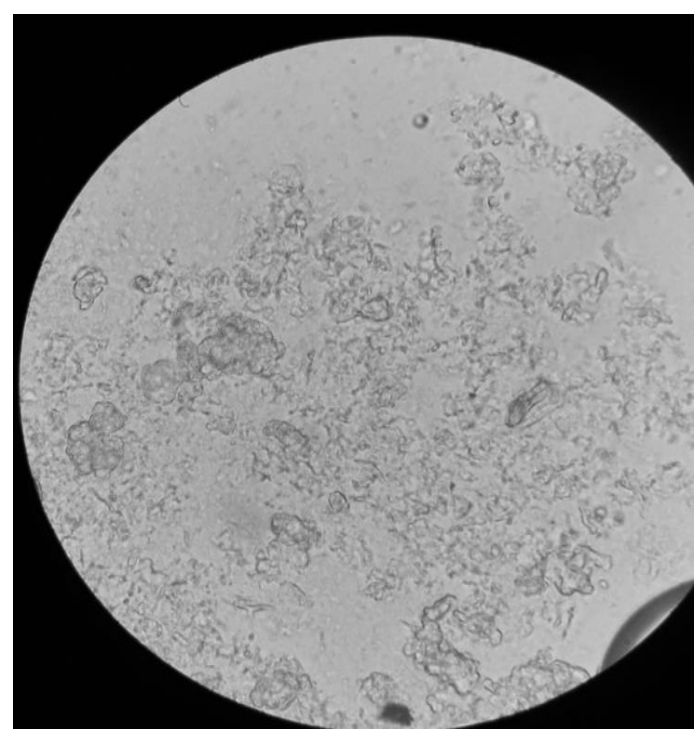

Figure 2. Calcium technical white soda

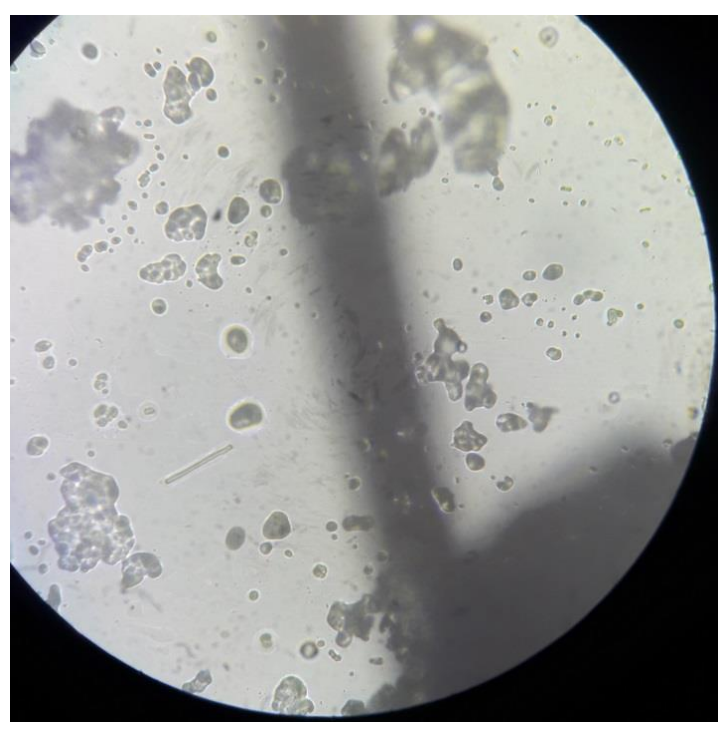

Figure 3. Calcium carbonate soda

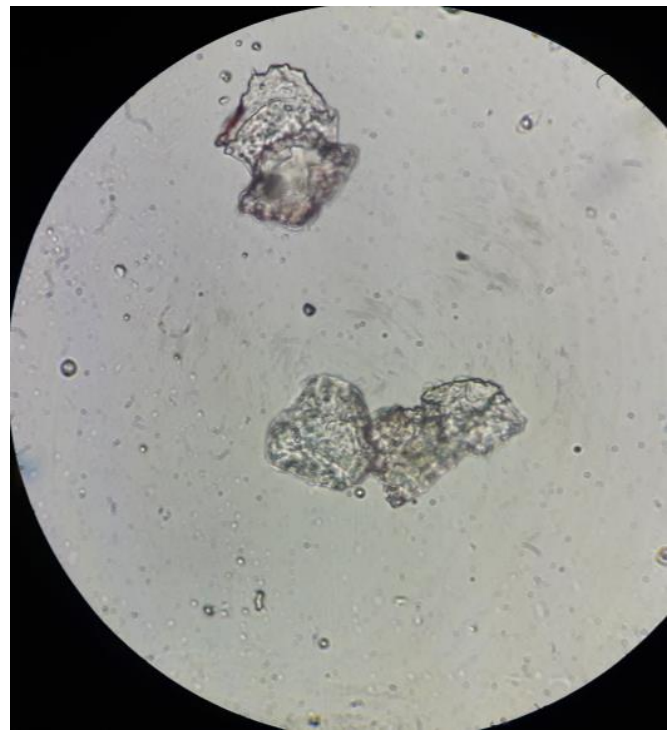

Figure 4. Technical shampoo 
The error between the microscopy method and the results of the laboratory analysis did not exceed $5 \%$. In the third stage, the dispersion composition of the phosphorite powder was analyzed using a sieve and microscopy. Phosphorite powder was tested in the laboratory model of the LM-2E saturation device for 5 minutes and the laboratory model of the SMTs-25 sorting sieve for 3 minutes in 3 stages. The size of the sieve grids was selected to be $20,60,100 \mu \mathrm{m}$. Based on the results obtained, the powders were divided into fractions as a percentage. The following are the cleaning efficiency indicators of dust cleaning devices used in the cleaning of superphosphate fertilizer dust and the results of laboratory analysis obtained. Analysis of the dispersion composition of the powder showed that it was $95 \%$ from 1-20 microns, $2 \%$ from $20-60$ microns, and $3 \%$ from 60-100 microns.

Table 1 shows the fractional amount of superphosphate dust, the cleaning efficiency of the TSN-15 NIOGAZ cyclone mounted on the aspiration section and the $\mathrm{C}-1$ hollow scrubber.

Table 2.

Amount of superphosphate powder by fractions

\begin{tabular}{|c|c|c|c|}
\hline \multicolumn{2}{|c|}{ Production of superphosphate mineral fertilizers } \\
\hline $\begin{array}{c}\text { Size of sieve } \\
\text { grids, mkm }\end{array}$ & $\begin{array}{c}\text { Granulometric composition, } \\
\text { \% }\end{array}$ & Cyclone\% & $\begin{array}{c}\text { Scrubber, } \\
\%\end{array}$ \\
\hline $1-20$ & 95 & $20 \%$ & $35 \%$ \\
\hline $20-60$ & 2 & $100 \%$ & - \\
\hline $60-100$ & 3 & $100 \%$ & - \\
\hline
\end{tabular}

Optical microscopy was also used to determine the dispersed composition of phosphorite dust (such analysis of particles in a biological microscope gives a relative error of $\pm 1.5 \%$. Bringing the dimensions to the mean gives a relative error of $\pm 3.4 \%$ ). By optical microscopy, a micro photo image of phosphorite powder is obtained. Hair fibres are used to determine the size of the dispersed powder and are divided into fractions in per cent. Given that the phosphorite is soluble in the liquid medium, it was not mixed with water. The imaging was performed on a DSM-310 camera and a LANGDORPSSESTENGER-1603201 SM001-CYANS biological microscope. Image processing was performed on a computer. When the magnification of the microscope was 400 times, the size of the mineral fertilizer powder was determined by comparing the percentage in the range of $1,100 \mu \mathrm{m}$ with the size of the hair fibre (Figure 5).

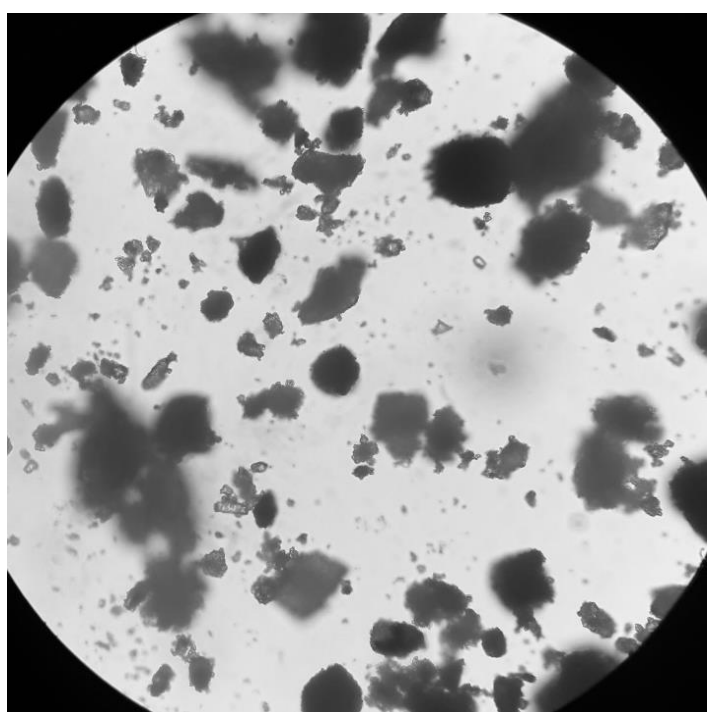

Figure 5. The appearance of phosphorite flour powder under magnification of SM001-SYANS 400 times

The error of laboratory analysis between the sieve and the microscopy method was $7 \%$. Hence, in experimental studies to determine the cleaning efficiency of the scrubber, it can be assumed that the average median value of the crushed particles is $\mu \mathrm{m}$ for the dust of phosphorite flour.

\section{Conclusion}

The calculations of the chemical reaction show that the most optimal option for the existing process is technical white soda with calcium, and the sodium fluoride precipitate formed in the reaction can be used as a primary raw material in other industries.

From the results of laboratory analysis, it can be concluded that in conducting experimental studies on the device it is advisable to use a $30 \%$ aqueous solution of technical white soda with calcium. 


\section{References:}

1. Isomidinov A.S. Development of effective methods and devices for the purification of dust gases from the chemical industry: Diss. PhD. - Tashkent, - 2020. - 118 p. (in Uzbek).

2. Isomidinov A.S. Issledovanie gidravlicheskogo soprotivlenija rotorno-fil'trujushhego apparata [Research of hydraulic resistance of rotor-filter apparatus]//Universum: tehnicheskie nauki. - 2019. - №. 10-1 (67) (in Russian).

3. Isomidinov A.S., Tojiev R.J., Karimov I.T. Rotor device for cleaning dusty gases by wet method // Scientific and technical journal of Fergana Polytechnic Institute. - Fergana, 2018. - №1. - pp. 195-198.

4. Tozhiev R.Zh., Akhrorov A.A. Analysis of phase separation layers and equations of mass transfer coefficient in the gas-liquid system // Scientific and technical journal FerPI-Fergana. - 2020. - №4. - pp. 177-180.

5. Ahrorov A.A. U., Isomiddinov A.S., Tojiev R.J. Gidrodinamika poverhnostno-kontaktnogo jelementa rotor-fil'trujushhego pyleulovitelja [Hydrodynamics of rotor-filter dusty gas collector's surface contact element] //Universum: tehnicheskie nauki. - 2020. - №. 8-3 (77) (in Russian).

6. Kouzov P.A. Osnovy analiza dispersnogo sostava promyshlennyh pylej i izmel'chennyh materialov [Fundamentals of the analysis of the dispersed composition of industrial dusts and crushed materials]. - Himija. Leningr. otd-nie, 1974. - 280 p. (in Russian).

7. Isomidinov A.S. Chang namunalarini tanlash va ularning dispers tarkibini analiz qilish [Selection of dust samples and analysis of their dispersed composition] // Global science and innovations 2019: Central Asia. VMezhdunarodnoj nauchno-prakticheskoj konferencii. - Astana, 2019. - pp. 264-268. (in Uzbek).

8. Isomidinov A., Axrorov A., Karimov I., Tojiyev R. Application of rotor-filter dusty gas cleaner in industry and identifying its efficiency //Austrian Journal of Technical and Natural Sciences. - 2019. - №. 9-10.

9. Tozhiev R. Zh., Isomiddinov A.S., Ahrorov A.A. U., Sulajmonov A.M. Vybor optimal'nogo absorbenta dlja ochistki vodorodno-ftoristogo gaza $\mathrm{v}$ rotorno-fil'troval'nom apparate i issledovanie jeffektivnosti apparata [Choosing an optimal absorbent for purification of hydrogen-fluoride gas in a rotary filter device and research the effectiveness of the device] //Universum: tehnicheskie nauki. - 2021. - №. 3-4 (84). - S. 44-51. (in Russian). 